\title{
The future of Turkey in the European Union
}

\author{
Aylin Güney* \\ Department of Political Science, Bilkent University, Ankara, Turkey
}

\begin{abstract}
Turkey's future in the European Union (EU) is a subject of intense debate both in Europe and in Turkey today. Although Turkey first applied to join the EU 45 years ago, it is the only candidate country, which has not yet started accession negotiations. On the one hand, any future enlargement that includes Turkey is a controversial topic for the EU, since Turkey would be the only Muslim member in the EU, which has accepted 10 new members in May 2004. On the other hand, it is too late to exclude Turkey from the future of the EU since it has put the issue of the EU accession at the top of its national agenda and is the only candidate country that has completed the Customs Union with the EU. This article aims to explore future scenarios regarding Turkey's inclusion to or exclusion from the EU and assess their short and long term implications.
\end{abstract}

(C) 2004 Elsevier Ltd. All rights reserved.

\section{Why does the future of Turkey in the EU matter?}

The future of Turkey in the EU has become an important question that deeply concerns both the EU and Turkish sides, and the Turkish case seems to remain as the most problematic enlargement that the EU will have to handle in the near future. The importance of the Turkish case in the enlargement scheme of the EU stems from five main factors: first, despite the 'principle of inclusiveness' [28] which is a finding idea of the EU, Turkey is the only remaining candidate country which, despite having signed an Association Agreement with the EU 40 years ago in 1964, has not yet even started accession negotiations. The enlargement to include Turkey has been quite controversial within the EU itself since there are differences of opinion among the member states, both supporting and rejecting the idea of Turkey joining in the union. Turkey's longstanding

\footnotetext{
* Fax: +90-312-2902742.

E-mail address: gaylin@bilkent.edu.tr.
} 
relationship with the EU has, therefore, put the EU in a difficult situation that is best reflected in the following statement of the EU Commissioner for Enlargement, Gunther Verheugen: "This decision to accept Turkey was made long ago. For decades, Turkey has been told that it has prospects of becoming a full member. It would have disastrous consequences if we now tell Turkey: actually we did not mean this at all" [13].

Second, a future enlargement to include Turkey would be a unique experience for the EU since Turkey will be the only Muslim country. This factor is all the more problematic because of Turkey's large population of 70 million who would join a union that is often referred to as a 'Christian Club'. This has created a 'Turco-phobia' among some of the Europeans, as was revealed in the statements of the Head of the Convention on Europe, Valerie Giscard D'Estaing, on the eve of the decision regarding the date for start of accession negotiations with Turkey. He stated that Turkey does not have a place in the EU since 'it has a different culture, a different approach, a different way of life'. For these reasons, he claimed that admitting Turkey would be the end of the European Union [7].

Third, the topic is also very important since the 2004 enlargement of the EU on 1 May 2004 will most likely pose additional challenges to the future of EU-Turkey relations. These challenges will primarily concern the 'problem of digestion' of the 10 candidates and two prospective-candidate countries in the near future and may cause attention to be diverted more to 'deepening' than 'widening' issues. It has become obvious since the Nice Summit in 2000 that the EU has been striving to find ways to tackle the problems that could emanate from this enlargement-it is most expensive yet. It is under these new circumstances, i.e. an EU with 25 members, that the Turkish case will be handled in the near future. In addition, it is obvious that the Central and Eastern European Countries (CEECs) will compete with the Mediterranean states, including Turkey-in case it becomes a member in the future-for scant development resources [8], most of which are the structural funds.

Fourth, quite apart from all the above mentioned factors, the future of Turkey in the EU is deemed just as important in its relation to the EU's security environment. Turkey, bordering on the most volatile region of the Middle East and the political regimes of Iran, Iraq and Syria, seems to be an important bulwark against Islamic fundamentalism and the challenges to European security that could stem from political instability in the Middle East and the Mediterranean. Yet, although it also acts as a bridge to secure the interests of the European countries in the region, Turkey is the only NATO and Western European Union (WEU) member, which is not a full member of the EU.

Finally, from the perspective of Turkey, the future in the EU is also very important since it is regarded as an aspiration that will change the whole face of Turkey. It has always been seen as a very important component of westernization as well as modernization praised by Mustafa Kemal Atatürk, the founder of the Turkish Republic in the early 1920s. Therefore, most of the Turkish population regards its candidacy as a matter of 'national pride' and places the utmost importance on becoming a full member. Even the recent general elections in Turkey in which and the religiously-oriented Justice and Development Party (Adalet ve Kalkınma Partisi-AKP) came to power in a victory that gave them a clear parlimentary majority, did not mark a change in Turkey's policy towards the EU. The official position that expects the EU to give a date for the start of the accession negotiations for the EU in Copenhagen was stronger than ever. 


\section{Turkey at the doorstep of the EU: in or out?}

The recognition of Turkey as a candidate for accession at the Helsinki European Council in December 1999 opened a new page in relations between Turkey and the EU. As foreseen in the Helsinki European Council conclusions, the EU Commission started to prepare an Accession Partnership for Turkey, which was adopted on 8 March 2001. After the approval of the Accession Partnership by the EU, the Turkish Government announced its own 'National Program for the Adoption of the EU Acquis' on 19 March 2001 and submitted it to the European Commission the same month. The National Program has been produced with a careful assessment of the short and medium term priorities as spelled out in the Accession Partnership. Within the past 3 years, Turkey has taken a number of important steps towards this end.

The most important among these was the major review of the 1982 constitution. Thirtyfour articles of the Turkish Constitution were amended in 2001 in accordance with the provisions of the National Program. Seven reform packages have passed through the parliament. The packages of constitutional amendments have covered a wide range of issues, such as improving human rights, strengthening the rule of law, restructuring democratic institutions, increasing freedom of association and the right to assembly, as well as gender equality and child protection and adoption of a new civil code. In addition, the reform packages have amended various laws regarding the legal basis for the detention and sentencing of many intellectuals for expressing their views, extended further the scope of freedom of thought and expression and freedom of the press. They have reinforced measures for the prevention of torture and ill-treatment, and introduced stronger deterrents against human rights violations by public personnel.

The most remarkable of these reforms were those abolishing the death penalty, lifting legal restrictions on individual cultural rights, making retrial possible in the light of the decisions of the European Court of Human Rights, ensuring the right to property of community foundations belonging to official minorities in Turkey, providing the legal basis needed for the activities of foreign foundations in Turkey, introducing new definitions and measures to deal with illegal immigration. Together, these mark a radical break with the long history of statism.

The new government, which was formed after the general elections of 3 November 2002, prepared two further legislative packages. The first legislative package, the socalled 'Copenhagen Package', was submitted to Parliament on 3 December 2002. It was drafted with due regard to the evaluation made in the EU's 2002 Regular Report on Turkey. The purpose of this package was to reinforce the reform process and eliminate certain ambiguities, especially with respect to implementation. With the adoption of this package, all legal impediments to the prosecution of public officials accused of resorting to torture and ill-treatment will be removed. By this, the Turkish government has declared 'zero tolerance' against torture and ill-treatment and alerted all public officials accordingly [39]. As part of the reform packages, the role of the National Security Council (NSC), which is generally seen as reflecting the 'political role' of the Turkish military, was also amended. The new provisions aim to limit the role of the NSC in Turkish politics, primarily by increasing the number of civilians in the council. 
In the light of all these reforms that have been diligently carried out by Turkey, the Presidency Conclusions of the Copenhagen European Council held on 11-12 December 2002 stated that

It strongly welcomes the important steps taken by Turkey towards meeting the Copenhagen criteria, in particular through the recent legislative packages and the subsequent implementation measures, which cover a large number of key priorities specified in the Accession Partnership. The Union acknowledges the determination of the new Turkish government to take further steps on the path of reform and urges in particular the government to address swiftly all remaining shortcomings in the field of the political criteria, not only with regard to legislation but also in particular with regard to implementation. The Union recalls that, according to the political criteria decided in Copenhagen in 1993, membership requires that a candidate country has achieved stability of institutions guaranteeing democracy, the rule of law, human rights and respect for and protection of minorities [24].

The Presidency Conclusions additionally stated that the Union encourages Turkey to pursue energetically its reform process. If the European Council in December 2004, on the basis of a report and a recommendation from the Commission, decides that Turkey fulfils the Copenhagen political criteria, the European Union will open accession negotiations with Turkey without delay...in order to assist Turkey towards EU membership, the accession strategy for Turkey shall be strengthened. The Commission is invited to submit a proposal for a revised Accession Partnership and to intensify the process of legislative scrutiny. In parallel, the EC-Turkey Customs Union should be extended and deepened. The Union will significantly increase its pre-accession financial assistance for Turkey. This assistance will from 2004 be financed under the budget heading 'pre-accession expenditure' [24].

As the conclusions indicate, the future of Turkey in the EU will depend to a great extent on the decision at end of this year, which therefore carries utmost importance for both sides since the EU is expected to give a date for the start of the accession negotiations with Turkey. Section 3 will explore some short-term and long-term future scenerios in this regard.

\section{Future scenerios}

\subsection{Scenerio I: 'yes' to Turkey}

This scenerio assumes that the EU will give a date to Turkey for the start of accession negotiations in 2005. The decision will be taken primarily because of the positive steps taken by Turkey to meet the criticisms of the EU. The EU will express its satisfaction both regarding the fulfilment of the Copenhagen criteria and Turkey's foreign policy towards the Cyprus problem. Regarding the Copenhagen Criteria, Turkey will pass more legislation revising the status of the Turkish military in Turkish politics and regarding the amelioration of the human rights records. It will also take important steps to liberalize its economy further, take measures against corruption, etc.

The Cyprus problem, which used to act as an obstacle in the future development of relations between the EU and Turkey, will no longer do so. This will be primarily due to 
the Turkish attitude and its implicit influence on the Turkish Cypriot people to accept the Annan Plan by voting 'yes' in the referendum held on 24 April 2004. The Turkish attitude vis-à-vis the Cyprus problem will continue to increase its credibility in the eyes of the EU member states which will eventually think that Turkey and the Turkish Cypriots are really longing for a solution towards the settlement of the Cyprus problem.

\subsection{Scenerio II: a conditional 'yes' to Turkey}

This scenerio also assumes that the EU will make a positive decision about Turkey's membership by giving a date for the start of the accession negotiations in 2005 yet due only to purely political and strategic reasons. Turkey's membership of the EU will take place only when the international situation allows for it. In other words, fulfillment of the Copenhagen Criteria will not provide a sufficient motivation for the EU countries to allow Turkey to become a member. Rather, the main motivations are concern over oil and competition for transatlantic markets.

\subsubsection{The concern over oil}

The recent war in Iraq will probably encourage the EU to develop mechanisms to act in greater harmony, while also avoiding being excluded from the power structures that would control oil supplies in the Eastern Mediterranean and the Middle East. There are two important reasons why the EU may be interested in full membership for Turkey: first the Bakü-Ceyhan oil pipeline that will bring Caspian Sea oil to the Mediterranean through the territory of Turkey; second, the difficult post-war situation in Iraq and the increasing American control of the Iraqi oil supplies. Turkey, as a neighbor to Iraq and as a host to a pipeline that brings Iraqi oil to the Mediterranean, will have great geostrategic importance for the EU because in the foreseeable future, the only access to the Mediterranean for both pipelines seems to be through Turkish territory.

\subsubsection{The transatlantic competition for markets}

The other reason why the EU may be more interested in accepting Turkey as a full member has to do with the increasing American power in the Middle East and the Mediterranean. As the United States will have a foot in the Middle East from establishing a firmer presence on Iraqi territory, the EU will have to increase its power in order to cope with American power in these regions and cannot do it without securing Turkey to its side. A Euro-Mediterranean partnership which currently envisages the creation of a free trade zone across both the north and south Mediterranean by the year 2010 will probably accelerate to balance the increasing presence of the United States in the same region. The EU, after possibly admitting Bulgaria and Romania in 2007, may consider opening accession negotiations with Turkey.

\subsection{Scenerio 3: 'no' to Turkey}

In spite of all the variety of arguments that support Turkey's membership of the EU, the likelihood of another scenerio is worth considering. This is the scenerio in which in the near future the EU does not even give a date for the start of the accession negotiations 
and tries to keep Turkey on the sidelines by emphasizing the 'insurmountable' differences between the two sides that have been expressed from time to time by important European leaders. The factors which may act as future obstacles to Turkey's membership of the EU can be considered under four main headings.

\subsubsection{Post-2004 enlargement challenges}

One of the major factors which has influenced to a great extent the future of Turkey's relations with the EU is the enlargement of the EU by including 10 new countries (Poland, Hungary, the Slovak Republic, the Czech Republic, Slovenia, Estonia, Latvia, Lithuania, Malta and Cyprus) on 1 May 2004. The prospective date for the 'acceding countries', namely Bulgaria and Rumania seems to be 2007. Turkey is the only country among the previous 13 candidates, which, despite having applied to the Union the earliest, has been granted neither membership status nor an exact negotation date.

One of the main implications of the 2004 enlargement for Turkey is that Turkey's EU candidacy should be evaluated within the larger framework of enlargement, and that Turkish membership will not be determined solely by the country's ability to meet the accession criteria, but also by EU-specific factors that impact on the Union's approach to Turkey [14]. The European Commission officials are still discussing the logistics of how an EU of 25 member states can function efficiently and effectively in the post-2004 enlargement period. The power relations between the EU member countries are also important in assessing the impact of the 2004 enlargement upon Turkey. For example, German foreign minister Joschka Fisher has expressed his vision of a federalized Europe in which he advocated the idea of a 'core' suggesting that a group of more advanced countries should take the position of, 'center of gravity' [5]. The EU with 25 member states has become a giant that nobody really knows how it will function. Yet, it is for sure that the decision for the start of the negotiations with Turkey will necessitate the votes of all the newcomers as well, who will, most probably not prefer Turkey to get a share in the structural funds. These 10 new countries have brought with them unique histories, cultures, attitudes to development and political priorities. They have full voting rights alongside the current 15 members. The functioning of the previous decision-making mechanisms with the inclusion of the 10 new member states seems to remain core concerns of the EU officials as well as statesmen, and these concerns will definitely shape significantly Turkey's position and how it will be perceived.

Historical evidence reveals that the EU has been from time to time bound by the objections of one or few countries which has a national stake in blocking relations between Turkey and the EU. The Greek veto over the Fourth Financial Protocol is a good example in this respect. As Müftüler-Baç argues, the protection of national interests against supranational authority has become a legitimate EU practice, especially after the so-called Luxembourg Compromise in 1966 [15]. Unanimity voting therefore makes the decisions of enlargement quite difficult. However, Turkey is not without allies in the EU. The candidate country Eurobarometer results (2001) indicate that the states which support the Turkish position the most are other Mediterranean countries, especially Spain and Portugal, due to their concern that acceptance of Turkey into the Union will strengthen the Southern cone of the EU as a lever against the Northern cone of Europe. 
Due to the institutional set up of the EU, the population of Turkey is a great concern on the part of the EU member states. With a voting weight corresponding to its population of nearly 70 million, Turkey will be the second most influential member in the decisionmaking mechanisms of the EU institutions, especially in the European Parliament and the European Council. Therefore, some the EU member states which consider Turkey as belonging neither to 'geographical Europe' nor to 'cultural Europe' express their concern from time to time that such a latecomer should not be able to play a major role in decisionmaking that will affect the future of all the EU member states. The impact of this concern was illustrated with the Nice European Council's decision to omit Turkey from the calculations of voting power in an enlarged Union [16].

\subsection{2. 'European' versus 'Turkish' identity}

One of the important aspects of Europe's future vision seems to encompass the creation of a European demos on the basis of common European values [30]. The enlargement process is a means whereby the EU is shaping its eastern and southern periphery in accordance with its own priorities. In this sense, the EU also defines being a European state according to certain criteria [18]. Since the demise of the strategic division of Europe into two blocs, the definition of borders of Europe has started to be questioned. Yet this inquiry did not concern the CEEC countries much due to their historical bonds with Western Europe. Eastward enlargement was not motivated just by political, economic and security interests on both sides, but it also had a moral dimension in reuniting Europe and reviving the pre-Yalta order [9]. In other words, the definition of Europe and 'Europeanness' has been linked closely to geography, politics and culture and therefore creates concern for some countries, such as Turkey [10]. The words uttered by the Head of the Convention Valerie Giscard d'Estaing who said "Turkey must never be allowed into the European Union... since it has a different culture, a different approach, a different way of life", were very much resented in Turkey. D'Estaing was unambiguous on the issue of the EU membership and stated that 'Turkey is a country that is close to Europe, an important country...but it is not a European country....Its capital is not in Europe, 95\% of its population are outside [32].' His words can be seen as a good indicator of how some Europeans still perceive Turkey. Likewise, although Germany has officially backs Turkey's bid, the Christian Democrats, who play a very important role in German politics, argue that Turkey's admission could be 'political suicide', alleging that Turkey's membership would 'overtax' the EU's capacity for integration and hinder economic growth within the bloc [27].

On the other hand, recent Eurobarometers reveal the fact that $77 \%$ of the Turkish population is not well-informed about the EU, its enlargement policies, or its internal political mechanisms. Therefore, accession to the EU will seemingly remain as a project of the Turkish elite that has not been well-presented to the Turkish public with its pros and cons. This lack of information becomes quite important especially when relations with the EU become a matter of domestic politics and are used as a tool of party politics rather than a national policy in Turkey. Therefore the first important problem remains the internalisation of the project of the EU membership by the masses in Turkey. This problem can only be overcome with a large-scale communication strategy that embraces all sectors of Turkish society, not the educated elite only. 
On the EU side, the situation is not very different since the lack of information about Turkey and misperceptions characterize European public opinion in most of the EU member states. The perceptions of Europeans are mostly shaped either by factors emanating from the internal political and social problems of the EU such as xenophobia due to high unemployment and illegal immigration, or by factors that stem from sui generis problems which would arise due to a possible future accession of Turkey to the Union. Among these factors are the following: the historical psychological legacy that the Ottoman Empire left behind, especially in countries that were once a part of the Empire; the huge population of Turkey, and the Turkish youth that might flow to Europe in case of a possible membership; the fact that Turkey is predominantly a Muslim country, and the perception of Islam as a threat-especially after the September 11 incident in 2001. In conclusion, the perceptions of the EU regarding Turkey are shaped both by its own current problems as well as the problems that Turkey is considered to bring in its 'backpack' if it were to become a member state.

\subsubsection{The Cyprus Imbroglio}

The Cyprus question has become closely linked to Turkey-EU relations and is even regarded by some as Turkey's key to the EU [21]. The application to the EU of the Greek government in Cyprus in the name of the whole island as well has started to complicate things regarding Turkey's position vis-à-vis the EU. Instead of making the solution of the Cyprus problem a pre-requisite for Cypriot membership, the EU seemed to prefer a tactical approach, thinking that the EU membership will act as a catalyst in the search for a solution to the island's division [4]. The declaration of Greek Cypriot President Tasos Papadopoulos on 7 April 2004, on the other hand, revealed that he himself did not approve of the Annan Plan and does not see this as the ultimate chance for a solution. What he implied in his speech to the Greek Cypriot population was that after Cyprus becomes an EU member, it would block any decision regarding Turkey's EU membership, until a solution is reached on better terms for the Greek Cypriots than the Annan Plan [12]. The Annan Plan, which was voted by referendum on each part of the island, has had a significant impact on Turkey's bid for opening accession negotiations with the EU. About $75 \%$ of the Greek Cypriots voted 'no' while $65 \%$ of the Turkish Cypriots voted yes.

Therefore, the Cyprus problem may continue to pose an important challenge to the future of Turkey in the EU, particularly in view of the accession of the Greek part of the island despite their rejection of the Annan Plan. There seems to be two important issues at stake: the lifting of the embargo on the Turkish Cypriot part, and the recognition of the Turkish Republic of Northern Cyprus. The statements of the EU officials before the referendum signalled that the EU is willing to change its attitude towards the Turkish Cypriot part. For instance, Javier Solana, on the date of the referendum stated that "if at the end of the day the southern part vote no and the other part yes, the relation with the other part will have to be also different. They cannot be left forever in the cold" [34]. After the referendum, Gunther Verheugen, the EU Commissioner for Enlargement, stated that "he felt 'cheated' by the Greek Cypriot leadership which has campaigned against the plan" [34]. Nevertheless, the EU did not change its attitude towards the Greek Cypriot part and they were admitted to the EU on 1 May 2004. This caused a serious resentment on the part of the Turkish Cypriots. The resentment can best be seen in the words of 
Prime Minister Mehmet Ali Talat who stated that "The side which accepts Annan Plan is outside the EU while the side which rejects the plan joins the EU with the claim of being the representative of the other side. That is out of question...we abided by our commitments. It is now the turn of the international community to prepare proposals...to alleviate or remove the isolation of the Turkish Cypriots" [35]. The same sort of resentment is also prevalent on the part of Turkey. According to Turkish Prime Minister Recep Tayyip Erdoğan stated "From now on nothing should be the same, and the EU must now initiate a process and act to conform with its pledges to ease the impact of an embargo on northern Cyprus" [11]. Turkey is also pressing the EU to revise the terms of Cyprus's accession to the union, saying the results of the referendum have changed the bases of existing conditions [36].

Another major issue on the agenda regarding the Cyprus problem if the issue of getting international recognition in order to demonstrate that the Greek Cypriot rejection of the Annan Plan could lead to a permanent partition on the island. Although Turkey expected the support of the EU in this regard, Verheugen underlined that "the EU would get into direct contact with the Turkish Cypriot officials but cooperation does not mean recognition" [37].

Turkey also seems quite dissatistifed about the revisions that EU ambassadors agreed to make to entry regulations since the revisions fall short of meeting a firm Turkish demand for direct communication, transportation and trade links between the EU and Turkish Cypriots. The revisions envisaged that all goods produced in northern Cyprus could cross the 'green line', but they denied to propose any measure that would allow direct international air and sea links from the EU states to northern Cyprus.

One other problem is concerning the role of the Turkish military in the Cyprus problem. The military most recently voiced out its support for President Rauf Denktas who strongly opposed the Annan Plan. On this matter, the AKP government and the military seem to pursue different policies which may also affect the future course of Turkey's policy towards Cyprus as well as the EU.

In the light of all these recent developments, what the future holds for the Turkish Cypriot part is quite uncertain. This uncertainty on the part of EU's future Cyprus policy as well as a growing future resentment on the part of Turkish Cypriots and Turkey may act as important challenges to the future of Turkey's relations with the EU. Therefore, the Cyprus problem will continue to occupy an important place in determining the future relations of Turkey with the EU. Therefore, the EU policy of acting as a catalyst in Cyprus may have some negative consequences for Turkey's bid for the EU membership, if Turkey's expectations are not fulfilled by the EU's Cyprus policy in the near future. This is because there has been and will continue to be an essential overlap between hardliners on the Cyprus conflict and the most nationalist and euro-sceptic forces in Turkey, as those who are sceptical of Turkey's future in Europe seem to be persistent in their effective opposition to the unification of Cyprus [33].

\subsubsection{The EU's dilemma of deepening versus widening}

One of the most critical tasks that the EU has been dealing with is the future of Europe itself and what kind of regime model it will adopt. The models vary from 'A European Confederation' to 'A European Kind of Switzerland' or 'Canadian-type European 
Federation' [3]. The future of Europe has been a major issue since the signature of the Amsterdam Treaty in 1998 due to fears inherent in rapid change within the nation-state and the different effects of the EU policies on member states and their citizens [29]. The Nice European Council of December 2000 called for a deeper and wider debate about the future development of the EU. To this end, a declaration on 'The Future of the Union' was annexed to the Nice Treaty and the debate was formally launched in 2001. Jan Zielonka argues that 'although the future EU is usually seen as a new type of Westphalian federal state with a central government in charge of a given territory with clear-cut borders, an enlarged EU would more closely resemble a neo-medieval empire with serious practical and conceptual implications [40].' He argues that the EU increasingly acts in concentric circles due to various opt-outs negotiated by individual member states in the areas of foreign, monetary and social policy. In addition, as a result of the effects of globalization, the EU lacks a strong and coherent sense of cultural identity, let alone a European demos or patria [41]. This ambiguity regarding the EU's own future will not only have clear implications upon Turkey's future accession to the EU but will shape the former's integration within the EU after a possible accession.

\section{Future prospects}

Turkey's future in the EU will be determined to a great extent by the answer to the following question: Will the future of the EU be determined by religious and racial boundaries, or will it be one that reaches out to embrace the diversity and unity of a much broader geography? The answer will also indicate if the EU can survive in the light of future challenges that it will face [6]. The future of Turkey in the EU will be determined largely by the integration of the new member states. The duration and success of the EU's 'digestion period' [1] will help to determine the time frame for Turkey's future accession to the EU. Thus the eventual acceptance of Turkish membership will be a political decision, and it will depend not only on progress made by Turkey but also on the political preferences of the EU member governments at the moment of choice [22].

In the short-term, 2004 and 2005 will be crucial years for Turkey-EU relations since they may affect strongly how EU-Turkey relations will develop, especially after the European Council Conclusions in December 2004. Although the opening of negotiations with Turkey constitutes a preliminary step towards the EU membership in the long term, it will be a crucial decision, both for Turkey and the EU. If the bid is successful, Turkey will become definitively anchored to the EU. Most likely, this will be followed by positive political and economic results for Turkey and will lead to a relaxation of the tension between the EU and Turkey.

In the long-term, the EU's decision will be more about its own identity and its own future than the eligibility of Turkey. It will decide whether it will face the challenges of an emerging new world; whether it is capable of seizing the new economic, historical and cultural opportunity; whether it can contribute to the embracing of civilizations rather than 'clash' of them [31]. It is very important for the EU to send signals to Turkey about its seriousness. Otherwise, the EU option will lose its credibility in Turkey and strengthen a feeling of betrayal within Turkish society. The content of the decisions will also affect to 
a great extent how the issue of the EU will be exploited in domestic politics to garner votes. A postponement of the date for the start of negotiations may increase the tensions within the Turkish public who already feel somehow alienated from the EU and who bear the general feeling that "whatever we accomplish, we will never be allowed to step inside". The Turkish Prime Minister Erdoğan has recently stated that "If the EU does not give the expected go-ahead it will not be difficult for Turkey to channel its huge potential in another direction". He also added that ".... negative response from the EU would both disappoint the Turkish people who have formed its will towards the European values and damage the philosophical basis of the Union irreversibly" [38].

Unless the EU injects some energy and motivates Turkey by giving a prospective date for the start of negotations, it seems that, especially after the enlargement of May 2004, EU-Turkey relations may go down the drain once again, and unfortunately the Turkish economy is too fragile to carry the extra pressure that this would generate. If the EU decides to initiate accession negotiations, even if the eventual membership takes a long time, the decision will lift the pressure, especially on Turkish public opinion; will erase the current feeling of deprivation, and eventually will ease relations between the two sides.

On the other hand, the image of the EU in the eyes of Turkey is quite controversial since although some countries adopted a positive attitude, others adopted a negative attitude towards the decision regarding Turkey. In other words, the EU member states seemed to be divided over the issue. While Spain, Great Britain, Belgium, Portugal, Italy, Luxembourg and Greece have earlier declared their support for a date to be given to Turkey for the start of the accession negotiations, France, Denmark, Netherlands, Sweden and Ireland generally think that a date can be given only after observing the implementation of the reforms that Turkey has passed through its Parliament [25]. While France and Germany talk of the year 2005, depending on the Progress Report prepared by the Commission, Germany, Spain, Italy, Great Britain and Greece think that Turkey should be given a date by the end of 2004, and according to Belgium this date should be given as soon as possible [26]. According to the recent declarations, it seems that Austria and France are the leading countries who oppose Turkey's membership [20], whereas Belgium and Germany have been sending positive signals regarding this matter [2].

The decision on whether and when to open accession negotiations on full Turkish membership in the EU will probably be primarily political, since the measurement of the progress regarding the Copenhagen Criteria will be very difficult and will remain to the subjective discretion of the individual member states of the EU. Although the Copenhagen Criteria are set forth as an important obstacle that will determine the future of Turkey's accession, Turkey's institutional role in the Union's common foreign and security policies, its significant military capabilities and its pivotal geographical position will continue to determine Turkey's strategic importance for the EU in the post-cold war era, due to the former's role in the EU's possible military operations and strategic concerns. Europe requires a stable, modernizing and democratic Turkey to keep radical Islam away from Europe's borders [23]. If this can be supported by the EU membership, then it will make the EU membership for Turkey more likely. Turkey's role in the Middle East-especially regarding Iraq and Israel, its geostrategic weight in Southeast Europe and the Balkans and finally its role in the Caspian region as an energy corridor for Europe [17] will help shape the attitude and policies of the EU in the post-2004 enlargement years. The war on Iraq has 
revealed the importance of Turkey for the stability of the region once again and it is one of the arguments of the Turks that there are also plausible reasons for the EU to view Turkey's membership positively from a security perspective [19].

\section{Conclusion}

In conclusion, it seems quite probable that Turkey will continue its European orientation in the foreseeable future no matter what kind of response it gets from the EU. The realization of the 'yes' scenerios will most probably depend on the strategic importance of Turkey for the EU. In any case, the even though the accession negotiations start in the short-term, their completion and the eventual accession to Turkey to the EU will probably not take place in 10-20 years. If Turkey becomes a member at the end, it will definitely be facing a quite different Europe than it is today. Europe, in the meanwhile, will have at least 27 members with varying support for Turkey's integration into the EU. Turkey will be one of the countries, which will have the highest number of seats in the European Parliament and the European Council due to its high population and will most likely influence the decision-making process in the EU.

On the other hand, it is also possible that due to the obstacles mentioned earlier, a future decision for Turkish accession will stay in a limbo. Although the EU may decide to give a date for the start of the accession negotiations, it will not be able to reach a consensus among the member states regarding full membership of Turkey to the EU. In this case, although the official Turkish position will most probably continue its European orientation, the relations between Turkey and the EU will go through serious crisis due to eroding confidence of the Turks in the EU. The most important political implication of this scenerio might be Turkey's more intraverted and nationalistic stance or a probable rise in the votes of the Islamic parties with a strong anti-European and anti-Western rhetoric and practice. The economic implications of such a scenerio may suggest a serious economic crisis due to the outflow of foreign capital from Turkey on whose economy is highly dependent. This will lead to further isolation of Turkey and a subsequent social and economic instability in the country.

No matter which scenerio may come true, it is important to note that the 45-year old Turkey-EU relations have come to an important turning point. The future course of events will be determined by the developments that will take place within the EU; by the degree to which Turkey will be able to meet the EU's demands; and by the international context that will frame the future of Turkey in the EU.

\section{References}

[1] C. Baydarol, Genislemenin Avrupa Birliği’ne Getirdiği Sorunlar in Türkiye Avrupa Birliği İliskilerinde Gelismeler ve Gelecek (The Developments and Future regarding Turkey-European Union Relations), Anadolu Üniversitesi Yayınları, Eskisehir, 2001 p. 60.

[2] Belgian Foreign Minister stated that a seat awaits Turkey in the EU and the German Chancellor Gerhard Schroeder stated that Turkey can rely on Germany to keep its word of support for Turkey. 
[3] P. Coffey, The future of Europe, Edward Elgar Publishing House, Aldershot, 1995 pp. 162-163.

[4] T. Diez, Last exit to paradise? The European union the Cyprus conflict and the problematic catalytic effect, in: T. Diez (Ed.), The European Union and the Cyprus Conflict. Modern Conflict, Post-modern Union, Manchester University Press, Manchester/New York, 2002, pp. 139-162.

[5] J. Fischer, From conferderacy to federation: thoughts on the finality of European integration in: C. Joerges, Y. Meny, J.H. Weile (Eds.), What Kind of Constitution for What Kind of Polity?, Robert Schuman Center for Advanced Study, Florence, 2000, pp. 19-30; citedin A. Bozoki, Hungary and the New Central Europe in the Context of European Integration in: C. Joerges, Y. Meny, J.H. Weile (Eds.), in What Kind of Constitution for What Kind of Polity?, Robert Schuman Center for Advanced Study, Florence, 2000 p. 198.

[6] K. Fogg, Avrupa Birliği'nin Güncel Eğilimleri ve Türkiye (Turkey and Current Tendencies of the European Union), Tübitak Matbaası, Ankara, 2002 p. 8.

[7] For a detailed analysis of the civilizational aspects of Turkey's future membership to the EU, see A. Tekin, Future of Turkey-EU relations, Futures.

[8] R.H. Ginsberg, The impact of enlargement on the role of the European union in the world in: J. Redmond, G.G. Rosenthal (Eds.), The Expanding European Union. Past, Present, Future, Lynne Rienner Publishers, Boulder, 1998, p. 212.

[9] S.E. Kahraman, Rethinking Turkey-European union relations in the light of enlargement, Turkish Studies 1 (1) (2000) 6 .

[10] S.E. Kahraman, Rethinking Turkey-European union relations in the light of enlargement, Turkish Studies 1 (1) (2000) 6-7.

[11] Y. Kanl1, What now on Cyprus? Turkish Daily News, 26.4.2004.

[12] Live television program, NTV, 7 April 2004.

[13] M. Müftüler-Baç, Enlarging the European Union: Where does Turkey Stand?, Tesev Publications, Istanbul, 2002 p. 5.

[14] M. Müftüler-Baç, Turkey in the EU's enlargement process: obstacles and challenges, Mediterranean Politics 7 (2) (2002) 79.

[15] M. Müftüler-Baç, Enlarging the European Union: Where does Turkey Stand?, TESEV Publications, İstanbul, 2002 p. 31.

[16] M. Müftüler-Baç, Enlarging the European Union: Where does Turkey Stand?, TESEV Publications, İstanbul, 2002 p. 13.

[17] M. Müftüler-Baç, Turkey's Role in the EU's Security and Foreign Policies, Security Dialogue, 31 (4) 489-502.

[18] Ç. Nas, Turkey-EU relations and the question of identity in: M. Dartan, Ç. Nas (Eds.), The European Union Enlargement Process and Turkey, Marmara University, European Community Institute, İstanbul, 2002, p. 219.

[19] H.T. Oğuzlu, How to Interpret Turkey's Accession Process with the European Union? A Clash of Discourses, Perceptions, (December 2002-February 2003), pp. 51-83.

[20] On 7 April 2004, French Foreign Minister Michel Barnier told French National Assembly that France would oppose Turkey's entry into the European Union under current circumstances. The Austrian Social Democrat Part leader Alfred Gusenbauer lso stated on 11 May 2004 that Turkey odes not possess the maturity to become a member of the EU nor the EU have the maturity to accept Turkey. He said that accepting Turkey as a member country would be irresponsible without first achieving complete integration of all 25 members within the EU.

[21] F. Özbilgen, Cyprus: Turkey's Key to the EU BIA News Center 12 December 2003 reproduced in http:// www.bianet.org/2004/03/01_eng/news27402.htm.

[22] W. Park, Turkey's European Union candidacy: from Luxembourg to Helsinki-to Ankara?, Mediterranean Politics 5 (3) (2000) 42-43.

[23] W. Park, Turkey's European Union candidacy: from Luxembourg to Helsinki-to Ankara?, Mediterranean Politics 5 (3) (2000) 46.

[24] Presidency Conclusions, Copenhagen European Council, 12-13 December 2002.

[25] Radikal (İstanbul daily), December, 2002.

[26] Radikal (İstanbul daily), December 7, 2002.

[27] See http://www.dw-world.de/english/0,3367,1432A961819,00.html, 3.9.2003. 
[28] J. Solana, Turkey's EU Future, New York Times, 9 December 2002.

[29] V. Symes, C. Levy, J. Littlewood, The Future of Europe. Problems and Issues for the Twenty-First Century, Macmillan Press, London, 1997 p. xvii.

[30] A. Tekin, Future of Turkey-EU relations: a civilizational discourse, Futures.

[31] The 'clash' is borrowed from Samuel Huntington's famous work, The clash of civilizations. This point was also dealt by Ali Tekin, Future of Turkey-EU relations: a civilizational discourse, Futures.

[32] The Guardian, 9 November 2002.

[33] N. Tocci, Turkey's strategic future, Paper presented at the CEPS/IISS European Security Forum, Brussels, 12 May 2003, reproduced at http://www.iiss.org/eusec/tocci.htm, p. 5.

[34] Turkish Daily News, 24 April 2004.

[35] Turkish Daily News, 26 April 2004.

[36] Turkish Daily News, 27 April 2004.

[37] Turkish Daily News, 28 April 2004.

[38] Turkish Daily News, 5 May 2004.

[39] Turkish Ministry of Foreign Affairs, http://www.mfa.gov.tr

[40] J. Zielonka, How new enlarged borders will reshape the European union, Journal of Common Market Studies 39 (3) (2001) 50.

[41] J. Zielonka, How new enlarged borders will reshape the European union, Journal of Common Market Studies 39 (3) (2001) 52. 